\title{
Formation of Territorial Community as a Subject of Local Development
}

\author{
Mariana Blazhivska \\ Lviv Regional Institute for Public Administration of the National Academy for \\ Public Administration under the President of Ukraine, Ukraine \\ blazhivskam@gmail.com \\ https://orcid.org/0000-0001-5573-7577 \\ Petro Petrovskyi \\ Lviv Regional Institute for Public Administration of the National Academy for \\ Public Administration under the President of Ukraine, Ukraine \\ petro_petrovskyy@ukr.net \\ https://orcid.org/0000-0001-8521-2384
}

Received: 11. 9. 2020

Accepted: 5. 11. 2020

\section{ABSTRACT}

\begin{abstract}
The study contains an analysis of the essence of decentralization and its impacts on the creation of territorial communities. Scholarly views on the essence of the concept of 'territorial community' are presented and its features mentioned. The factors that determine the regional development of the territorial community as a subject of economic relations in the region have been identified. The legislative regulation of the process of creation and development of territorial communities is analysed and the shortcomings of the current situation are pointed out. The degree of decentralization over the period 2018-2020 is briefly analysed and a description of the methodology for assessing the viability of the created territorial communities is given. It is emphasised that the methodology of formation of affluent territorial communities is described in the 2015 Ukrainian legislation and approved by the resolution of 8 April No. 214 "The methodology of formation of affluent territorial communities". The calculated indicators are given on the example of the Stepanivska united territorial community and its prospects of development are estimated. Recommendations for improving the conditions of formation and development of territorial communities in the conditions of decentralization in Ukraine have been developed. The empirical methodology used in the study proved to be liquid and can be applied in practice to the formation of the territorial community as a subject of local development.
\end{abstract}

Keywords: administrative-territorial unit, decentralization, local self-government, territorial community

JEL: RO, H7O, H83 


\section{Introduction}

The territorial community as the main subject of local self-government in Ukraine has been the subject of study of many scholars, in particular Вaranovska T.M. (2014) defines a territorial community as a group of individuals who permanently reside in the relevant territory and are interconnected by territorially personal ties of a systemic nature. The scientist defines the territorial, integrative, intellectual, property and fiscal features as the main characteristic ones of the territorial community. This statement seems to be the most successful, so in the article the term "territorial community" will include this content and will consider the united territorial community in view of the features proposed by the scientist.

The understanding of the systemic changes in the environment, in which an objectively determined trend of increasing community autonomy is developing, which is taking place in world economics, has not yet been properly reflected in studies of decentralization in Ukraine. The available publications of a practical direction provide rich empirical material, however, unfortunately, do not advance in the direction of the theoretical comprehension of this phenomenon. Decentralization is deprived of a holistic scientific and theoretical justification, which leads to underestimation and disregard for its systemic consequences, which may contain both a multiplier potential for reform and significant risks.

The purpose of the study is to analyze the peculiarities of the formation of the territorial community as a subject of local development.

\section{Methods}

The research methods used in the study are: search on the available methodical and scientific literature with the analysis of the found material, comparison, classification, designing, clarification of causal relations, systematization, abstraction and concretization, analysis of documentation and results of activity of researchers on the problem of the conducted research.

\section{Results}

The decentralization reform aimed at creating a modern system of local selfgovernment in Ukraine is based on European values of local democracy development, empowerment of territorial communities, ensures economic development of individual territorial communities and the region as a whole. Regional development depends on the results of the territorial community as a subject of economic relations in the region, the performance of functions by the territorial community, the financial basis for the functioning of the territorial community. The directions of further research on the impact of the development of united territorial communities on regional development are the improvement of planning and strategic documents of communities, local programs; administration of tax and non-tax revenues; optimization of 
budget expenditures; settlement of procurement activities; deepening community asset management work; building an internal control system.

At the beginning of our study we will define the concept of "territorial community" in the views of scholars. According to the scholar-lawyer Bibik and Shapoval (2019), who accumulates the views given in the constitutional and legal literature regarding this term, the territorial community is the primary subject of the local government, consisting of individuals - residents (citizens of Ukraine, foreign citizens, refugees, internally displaced persons) who permanently reside, work in the territory of a village (or voluntary association in a common community of several villages), settlement or city, directly or through the municipal structures formed by them solve issues of local importance, have common communal property and are connected by individual-territorial ties of systemic nature. This definition reflects mainly the axiological and socio-political nature of municipal power.

Bulkovsky (2013) defines the territorial collective as a social community, which is formed within the common residence of citizens and based on socially necessary, socially conditioned activities carried out by a group of people united by interests in political, socio-economic and cultural life. Lipentsev and Yu. S. Zhuk in their study determined that the territorial community is the basis of local self-government in Ukraine and they revealed the process of formation of the local government system and the constitution of territorial community as its primary subject, which activates deep processes of political and socio-economic renovation of society and the state, which is objective and therefore an indispensable prerequisite and important factor in the reform process that takes place in our country and aims to build a democratic, legal and social state (Lipentsev and Zhuk Yu, 2015). Scientists Popok and Popov considered the territorial community (local community) as a set of individuals who permanently live in the certain territory and are interconnected by territorial-personal ties of a systemic nature (Popok, 2017). Thus, a feature of the territorial community is socio-demographic interaction, that is, neighborly relations, common rules and norms of behavior, a sense of belonging and involvement in community events, psychological identification of human interests with community interests, common moral and ethical values. Only such a social combination in the population makes it possible to understand such social cumulation, and hence the social orientation, the content of the municipal activities of the territorial community.

The Law of Ukraine "On Local Self-Government in Ukraine" determines the territorial community as a set of residents united by permanent residence within a village, town, city, which are independent administrative-territorial units, or a voluntary association of residents of several villages with a single administrative center (Article 1). It is the primary subject of local self-government, the main bearer of its functions and powers. Socio-legal structure of the multifaceted phenomenon "territorial community" contains the concept of population as a social community of inhabitants united by common activities, interests and goals to meet the needs of life, living environment, recrea- 
tion, education, communication (The Law of Ukraine "On Voluntary Association of Territorial Communities", 2015).

Among other legislative documents of Ukraine concerning the organization and functioning of territorial communities, the following can be singled out: the State Strategy for Regional Development for 2020, approved by the Cabinet of Ministers of Ukraine; the Law of Ukraine "On Amendments to Certain Legislative Acts of Ukraine Concerning Decentralization of Powers in the Sphere of Architectural and Construction Control and Improvement of Urban Development Legislation"; the Law of Ukraine "On Amendments to Certain Legislative Acts of Ukraine (Regarding Voluntary Accession of Territorial Communities)" facilitates the procedure of voluntary association of territorial communities, the right of communities to join the already established one under a simplified procedure; the Law of Ukraine "On Amendments to the Law of Ukraine "On State Registration of Legal Entities and Individual Entrepreneurs" and some other legislative acts of Ukraine on decentralization of powers for state registration of legal entities, individual entrepreneurs and public entities"; the Law of Ukraine "On Amendments to the Law of Ukraine "On State Registration of Corporeal Rights to Real Estate and Their Encumbrances" and some other legislative acts of Ukraine on decentralization of powers for state registration of corporeal rights to real estate and their encumbrances"; the Law of Ukraine "On Amendments to Certain Legislative Acts of Ukraine on Expanding the Powers of Local Self-Government Bodies and Optimizing the Provision of Administrative Services" (The Law of Ukraine "On the Local Elections", 2015).

Today, the issues of amending the Constitution of Ukraine on decentralization of power and the principles and procedure for resolving issues of administrative-territorial organization of Ukraine remain unsolved. Such amending will provide a legal basis for the adoption of a chain of laws needed to implement local government reform and territorial organization, which will form the basis for the formation of promising territorial communities and ensuring the universality of local self-government, mitigate contradictions in relations between local self-government and executive power by delimiting their powers in accordance with the principle of subsidiarity, refusal to delegate powers of district and regional councils. M. O. Baimuratov, analyzing the legislation on the local government, identifies the following characteristics of territorial community: 1) territorial, which is associated with the "location" of the local government at the village, town, city level as a territorial basis of municipal democracy; 2) integrative, according to which territorial community forms on the basis of the association of all residents living in a certain territory, regardless of whether they are citizens of the state (stateless persons who permanently live in a certain territory).

Highlighting such a category of entities as administrative-territorial units (ATU), we note that they are the subjects of legal relations and have their own status. The basis of territorial formation as a separate component of the territory of the state, in which the relevant authorities operate, is a certain territory and the population living in this territory - the territorial collective 
(part of the population of the state). Based on this, we can distinguish the following elements of the legal status of territorial entities: social purpose; competence (functions and powers); the order of formation (method of legitimization), change and liquidation; clearly defined administrative-territorial boundaries; internal organization (organization of power, its relationship with the central government and other territorial entities); responsibility. The content of these elements in their relationship allows determining the place and role of territorial entities in the system of territorial organization of states, in the process of their international cooperation.

Decentralization is the main, key reform for creating capable territorial communities and regional development of Ukraine. The Encyclopedic Dictionary of Public Administration defines that decentralization (from the Latin de - negation, centrum - the main center) is, first, the process of transferring some functions and powers from higher levels of government to lower ones (from central executive bodies to local executive bodies and local governments); secondly, in a broad sense, it is the weakening or abolition of centralization (European Charter of Local Self-Government, 2020), and the decentralization of state power is independence in approaches to governance, taking into account the diversity of local characteristics while maintaining unity in the main and essential; manifested in the delegation of powers from public administration to local government. In practice, decentralization is manifested as the transfer of part of the functions of public administration of central executive bodies to local executive bodies and local governments (Dudley, 2019).

The specificity of the territorial community as a subject of law should be determined in the context of existing theories of local self-government. It is noted that the territorial community is a common law category. Participation in various types of sectoral legal relations does not mean that it can be recognized as a subject only of different branches of law. At the same time, sometimes the relations in which the territorial community participates are so specific that it is expedient to consider them at once through the prism of several branches of law. To address this issue, it is advisable to talk about the existence of the right of the territorial community, which exists in two planes - objective and subjective. Most territorial communities emerged as subjects and gained the ability to participate in legal relations with the coming into force of the Basic Law of Ukraine. At the same time, the current legislation does not provide for a formalized procedure for their legal fixation in the unified state register of territorial communities. The territorial community becomes a subject of law from the moment of its origin, in accordance with the norms of the Constitution and laws of Ukraine (European Charter of Local Self-Government, 2020).

The territorial community as a subject of local self-government implements a number of functions, which are the main directions and activities of the territorial community to address issues of local importance. The functions of territorial communities should be classified: by objects (political, economic, social, cultural and environmental functions); by subjects (functions of territorial communities of villages, settlements, cities, districts in cities); techno- 
logical functions (financial-budgetary, material-technical, normative, informational, and system-forming). Since the territorial community is the subject of management, among the technological functions it is advisable to distinguish the general functions of management: planning, organization, motivation, coordination and control. The given classification, which includes object, technological and subjective functions of the territorial community as a subject of local self-government, allows, first, to reveal the activity of the territorial community, its focus on a specific object. Secondly, the technology of realization of functions of territorial community is found out. Third, the specifics of the activities of specific entities - territorial communities of villages, towns, cities, districts in cities, is pointed out (Seryogin, 2016).

In the territorial communities that are part of the UTC (united territorial community), social relations between its members are already established; they have improved because of their direct communication. Each of the communities had its own special content of everyday life, its own culture, traditions, values and history, thus, its own local identity. In UTC, this intellectual element is absent, for its formation and development, time and coordinated actions are required. In practice, residents of territorial communities that have joined the UTC, continue to live their lives, follow their traditions and preserve their own culture. This indicates that the intellectual and volitional connection between UTC members is still weak. Only in capable UTCs, where the quality of public services has significantly improved, landscaping activities are carried out throughout its territory and the communication between local communities is established, there are tendencies to form the culture and traditions of the UTC itself. At the same time, the population of Ukraine as a whole is skeptical about the processes of decentralization, reform of the administrative-territorial system and the formation of UTC.

O. Moroz offers the following list of features of the territorial community:

- common territory of existence (may include residence, territory, and possession of real property holding);

- common interests in solving life problems;

- social interaction in the process of realization of these interests;

- psychological self-identification of each member with the community;

- common communal property;

- payment of utility taxes.

Researcher Zhalylo (2019) gives the following features of the territorial community:

- territorial - cohabitation of persons (residents) who belong to the community in a certain area:

- integrative - territorial community on the basis of unification of all inhabitants of a certain territory, regardless of whether they are citizens of this state or not; 
- intellectual - the basis of the constitution of the territorial community is the common interests of residents, which have a specific nature and are manifested through a wide range of systemic individual-territorial bonds that arise between them;

- property - the territorial community is the subject of communal property rights;

- fiscal - members of the territorial community are payers of local taxes and fees (Svendsen, 2016).

However, in accordance with Art. 5 of the Law of Ukraine "On Local Self-Government in Ukraine" they constitute a system that includes: territorial community; village, settlement, city council; village, settlement, city mayor; executive bodies of village, settlement, city council; district and regional councils representing the common interests of territorial communities of villages, settlements and cities; bodies of self-organization of the population. Thus, the subjects (participants) of organizational and economic powers in the relations on privatization of communal property and relations on sale in the order of privatization of property are the bodies created by the corresponding local councils. The state commissions for commissioning of completed facilities (state acceptance commissions), the status of which is determined by the Procedure for commissioning of completed facilities approved by the Cabinet of Ministers of Ukraine 22 September, 2004 №1234, should be recognized as special subjects of organizational and economic powers in the field of construction (Skrypniuk, 2015).

The territorial community is the primary subject in the system of local self-government both in Ukraine and in foreign countries. Such associations are actively functioning in the countries with developed democracy, regardless of whether the state is federal or unitary in structure, and play an extremely important role in resolving issues of local importance. The necessity to focus on the experience of the world's leading countries in improving local self-government in Ukraine in general and the functioning of territorial communities in particular is substantiated. At the same time, the priority should be given to the issue of delimitation of the competence of local governments and public authorities.

The territorial community is active in various forms, the main of which are the forms of its direct expression of will: local elections, local referendums, general meetings of citizens at the place of residence, meetings, conferences, local initiatives, public hearings, recalls of deputies and elected officials of local self-government, individual and collective written appeals, surveys on local self-government, public examinations, public works, participation of residents in the work of local self-government, public discussions of draft acts of local self-government, rallies, demonstrations, campaigns, pickets, etc. In general, the forms of participation of members of the territorial community in addressing issues of local importance can be represented as:

- expression of residents' own interests, needs, requests (on the initiative of the population - rallies, marches, pickets, individual and collective appeals; 
on the initiative of bodies and officials of local government - the study of public opinion through surveys, observations, analysis of documents);

- consultations of members of the territorial community with bodies and officials of local self-government on solving local problems (holding "round tables", public hearings, conferences, forums, seminars, etc.);

- participation of residents in the activities of local governments (service in local governments, public expertise, discussion of draft local plans and programs, their implementation, local initiatives);

- direct participation of citizens in solving local problems (local referendum, bodies of self - organization of the population).

The forms of participation of territorial communities through local governments in economic relations are provided in a large number of legislative acts of Ukraine. Thus, according to the provisions of Part 5 of Art. 60 of the Law of Ukraine "On Local Self-Government in Ukraine" local governments on behalf of and in the interests of territorial communities in accordance with the law exercise powers to own, use and dispose the objects of communal property, including all property transactions, may transfer objects of communal property rights for permanent or temporary use by legal entities and individuals, rent them out, sell and buy them, use them as collateral, resolve issues of their alienation, determine in agreements and contracts the conditions of use and financing of objects, which are privatized and transferred to use and rent.

As noted by V. Negoda, the right of the territorial community to manage communal property is more or less specific (but not absolute) among these elements of the legal personality of the territorial community, but in this case it is not only direct, but and indirect (through local governments) management. This fact was given special attention in the monograph by Voytovych, where the author points to the need to recognize such a phenomenon as economic (civil and financial) legal personality of the territorial community, "which provides a real guarantee of territorial communities and local government in Ukraine" (The Law of Ukraine "On Voluntary Association of Territorial Communities", 2015).

Administrative supervision of the activities of local self-government bodies may be exercised by higher authorities only in accordance with the procedures and in cases provided for by the constitution or law, and providing that it "is intended only to ensure compliance with law and constitutional principles" (Klymenko, 2019). the case when it is carried out properly due to the tasks of central authorities entrusted to local governments.

\section{Discussion}

The range of subjects of local self-government bodies, just as subjects of organizational and economic powers, require for their own legal regulation, especially in view of the requirements of Art. 19 of the Constitution of Ukraine, a certain convergence of the content of legislative regulation and its appa- 
ratus on local self-government, as well as economic legislation in a single mechanism. We believe that for an extensive and effective legal mechanism of interaction between the two branches of national legislation - economic and municipal, it is necessary to make proposals for a number of additions to the text of the Civil Code of Ukraine, recognize local governments as a special subject of economic activity and to allocate economic activity of such bodies as a separate institute of economic and legal support of the activity of "local self-government bodies as a subject of economic legal relations". The Civil Code of Ukraine should define: first, the subjects and participants of organizational and economic powers; secondly, means and forms of state (communal) regulation of economic activity; third, methods of implementation, and so on.

By May 2020, there are 44 united territorial communities in Ukraine with an administrative center in cities of regional significance (hereinafter CRS), created from 133 councils and 982 UTCs, which were created from 4487 councils, including 564 rural, 262 town-settlement and 156 urban UTCs, while 49 united territorial communities are awaiting a decision on the first local elections. The highest index is observed in 2017, and since 2015, the dynamics of growth has been observed, and in 2018 the indicator decreased by 159 UTCs, and amounted to 140 united communities per year. The average number of councils united in one UTC is 4.5. Zhytomyr region has the largest number of united communities, namely 76, Dnipropetrovsk - 71, Cherkasy - 57, Zaporizhia - 56, Sumy region has 38 communities (Klymenko, 2019).

The peculiarity of voluntary unification of territorial communities is the unification of all territorial communities of the district, and the result of such unification is a situation, when the jurisdiction of the representative body of local self-government of the united territorial community completely coincides with the jurisdiction of the district council. The methodology for forming affluent territorial communities is described in Ukrainian legislation in 2015 and approved by Resolution No. 214 of 8 April "Methodology for Forming Capable Territorial Communities". The basis of this document is to develop a long-term plan of the territory and the formation of a mechanism for creating a viable community. The term "capable territorial community" is defined as a community that voluntarily seeks to unite with other nearby local communities, able to address local issues with the help of local sources of budget and qualified human resources in the interests of the inhabitants of such a community (The Law of Ukraine "On the Local Elections", 2015). The European experience shows that giving the right and resources to each already created community is not logical, because significant funds will be spent on the maintenance of the administration, but in the case of merging, several territories will reduce these costs, because such an apparatus will remain only one and will be in the most promising of the communities. It is clear that such a formation cannot be formed, for example, by a village council from Zaporizhia district and a village council from Ivano-Frankivsk, because this method takes into account the distance from the community center to the farthest village and should be no more than $25 \mathrm{~km}$. 
Criteria such as developed infrastructure, number of educational institutions, and availability of premises for various public services are taken into account, the number of school and preschool children should be not less than 250 and 100 people, in case of non-compliance of at least one of the above indicators with the calculation is not carried out (Klymenko, 2019). The calculation can be done independently, taking into account the indicators approved by the method, or online calculator, access to which is available from local councils. The disadvantage is the inaccessibility of the common people to it.

The main indicators of social and economic development that determine capacity are (Кyгylenko, 2015):

1. population (threshold quantity is 3000 people, indicating a low level and equal to 0.3 points, quantity above 7000 people is high level, which is 1 point, the intermediate value is between the previous two and is equal to 0.6 points);

2. the number of children enrolled in educational institutions (minimum value of 300 people, equal to 0.3 points, maximum more than 500 people -1 point, intermediate -0.6 points);

3. total integral area (threshold quantity - 200 sq. km., maximum more than 400 sq. km, intermediate from 200 to 400 sq. km. The number of points is similar to the mentioned above);

4. tax capacity index (up to 0.3 , maximum more than 0.9 , intermediate $0.3-$ 0.9 , the number of points is similar to the above);

5. the share of local taxes in the community's own income (maximum up to $20 \%$, maximum more than $40 \%$, intermediate $20-40 \%$, the number of points is similar to the above).

According to the defined coefficients, the total number of points scored indicates the capacity of the community, for example, the range from 1.5 to 2.1 for low capacity, from 2.2 to 3.8 for medium and 3.9-5 for high one. All types can function, among the two comparable, the one with more points will be chosen, but also the one with a low level can work, the only condition is that the number of such communities is not more than $10 \%$ per area.

The main stages of creating territorial communities include:

1. putting forward a proposal to establish an UTC, approving the procedure for discussion of this proposal by the community council, then a meeting is held, where further actions are decided, the decision of the council at the session accepts this initiation and identifies potential allies;

2. a letter is sent to the neighborhood councils, with a proposal to become one UTC, in case of agreement, the neighborhood councils carry out similar actions in paragraph 1 ;

3. a group of employees, who are engaged in further planning of the draft decision, is formed and after its development there is a process of consideration, improvement and approval; 
4. submission of documents for verification, after approval and compliance with all standards at the session make this decision on UTC;

5. the date of elections of all elected members of the community is approved. In order to equalize fiscal imbalances in the socio-economic development of local areas, their financial equalization of tax capacity was introduced. The equalization process is specified in the Budget Code in Article 99. To determine the need for one of the grants, a tax capacity index is calculated, which provides for the use of such items (Voytovych and Vorona, 2018):

1. population in Ukraine and in the united community (data are used from the State Statistics Service at the beginning of the year preceding the planned one);

2. actual PIT revenues in Ukraine and in the united community (data are used from the State Treasury Service for the last reporting budget period, at the beginning of the year preceding the planned).

The index itself is calculated by the following formula:

$$
\text { Itc }=\frac{\text { PITUTC }}{\text { PUTC }} \div \frac{\text { PITUKR }}{\text { PUKR }}
$$

where Itc is tax capacity index (the amount of personal income tax per capita to the average value); PIT $_{\text {UKR' }}$ PIT $_{\text {UTC }}$ are the amount of received PIT in Ukraine and promising UTC, for example, the calculation is for 2020, the value is taken for 2018; $\mathrm{P}_{\text {UKR }} \mathrm{P}_{\text {UTC }}$ - population in Ukraine and promising OTG, for example, the calculation is conducted for 2020, the value is taken on 01.01.2019.

The results of the calculation may vary within the following limits:

1. the value of the index is more than 1.1 - promising UTC needs a reverse subsidy, which of course is a positive factor, because the community has enough resources for its own population, and therefore $50 \%$ of the excess will be sent to less affluent local communities;

2. the value of the index is 0.9-1.1 - the community is able to independently perform its own and delegated powers and does not require additional resources;

3. the value of the index is less than 0.9 - a promising community needs to receive additional funds, for which a basic subsidy of $80 \%$ of the amount will be provided.

The practical implementation of the above-mentioned method will be given on the example of the territorial community of Sumy region. In Sumy region, by May 2020, 187 councils of different levels - rural, township, city-expressed a desire to unite in 38 territorial communities (Kyrylenko, 2015). Among them is Stepanivka village united territorial community of Sumy district of Sumy region, which was formed on October 29, 2017 (Klymenko, 2019). It includes 10 settlements that were part of two councils: Stepanivka village and Pidlisnivka village. Stepanivka village council was determined as the community with a high level of capacity, the total number of points according to the method is 
4.3. The population is more than 7 thousand people, namely on 01.01 .2018 -7.4 thousand people, this is the first evaluation criterion that showed a high level. The second point is the number of students studying in educational institutions on the territory on $01.01 .2018-1105$ people, according to this indicator, it shows high level of capacity. The area is in the criterion of low level, because it is $129,42 \mathrm{sq} . \mathrm{km}$. The share of local taxes in UTC's own revenues is $42.66 \%$. Tax capacity index as of 01.01 .2018 is 0.968 , the community is fully provided with its own income. We can see from the calculations that the community has never received a basic or reverse subsidy during the three years of its existence. The value ranges from 0.95 to 0.99 . The obtained data for Ukraine are almost identical to the data of the analyzed UTC.

The budget coverage ratio varies between 0.58-0.78, a sharp decline was detected in the second quarter of 2018, during another period the value of the indicator remains almost at the same level, indicating the inability of Stepanivka UTC to operate without transfers, i.e., to cover the expenses with only its own revenues. The value of the coefficient of budgetary stability exceeds the norm, only the fourth quarter of 2019 corresponds to the optimal value of 0.30 . Such dynamics testifies to the still existing dependence of the local budget on financing from state transfers. At the same time, 2019 was marked by a decrease in this indicator compared to 2018, which has a positive impact on the stability of the budget. The value of the coefficient of general tax stability during the study period is kept above the normative value and ranges from 0.55 to 0.73 , which indicates the fact that the community is partially able to cover local expenditures with tax revenues. The dynamics of the ratio of expenditures to transfers has a declining trend, in 2018 the value of the indicator exceeded the norm by 0.19 points maximum and minimum by 0.01 points, in 2019 by a maximum of 0.09 points, during the third, fourth quarters were in the normative value at 27 is 0.21 , and in 2020 in the first quarter at 0.25 . This trend is positive, as it notes that the impact of state support is gradually diminishing. It is impossible to calculate the share of subsidies in the total amount of transfers, because, as it was mentioned earlier, the community is self-sufficient and does not need equalization.

The interests of the territorial community itself arise and are manifested on the basis of the set of interests of its individual members (common interests, primarily in meeting social, communal, local cultural and other needs) and in the individualized interest of a particular individual - a member of the territorial community (personal interests that are manifested primarily in the field of communication at the local level, resulting in self-realization of the individual within the territorial community). The interests of a particular individual - a member of the territorial community are his municipal rights in the narrow sense, which arise in the process of realization of almost all their life aspirations. In this implementation, a particular resident is a subject-object of local self-government, concentrating in itself and showing outwardly its democratic charge and positive potential (Ignatenko, 2016).

Community development as a process consists of six main stages: social capital development, community organization, vision formation, asset identifica- 
tion, planning, implementation and evaluation. In addition, the development of the community as a result is expressed in the improvement of the living conditions of the community through the collective actions of various stakeholders, primarily through the participation of the public, which has a major role to play in this (The Law of Ukraine "On the Local Elections", 2015).

Development of social capital. The development of social capital as "properties of individuals in the social context" is, on the one hand, a prerequisite (first stage) that ensures development in the "chain of community development", and on the other - the result of community development.

Community organization. This stage focuses on mobilizing people within a particular territory or community. Community organization should be seen as a way to mobilize small groups of people to perform specific tasks. Although we consider an asset-based approach to community development, in the first stage, a problem-oriented approach is often used to organize the community, as it is easier to mobilize community members to solve a problem that directly affects them.

Forming a vision is one of the many methods, such as determining the future, which shows what the community will look like in the medium term. The basic idea is to accept, often by reaching some form of consensus, a vision of what the community should become over a period of time for a wide range of individuals, associations and organizations within the community, and to prepare an action plan to achieve that vision.

Identification of assets. This stage should include the collection and analysis of information, in particular through surveys of community members, and the compilation of asset maps based on the information obtained. The collection and analysis of information is important for understanding the circumstances that exist, the changes that take place within the community over time, and the applicability of the data collected. Asset mapping is an ongoing process. Its purpose is to identify the skills, knowledge and resources that the community has, and it is the first step towards understanding what the community has.

Planning. After receiving and analyzing all the necessary information and drawing up an asset map, you can draw up a community development action plan based on the maximum use of available assets, taking into account the views of community members. The action plan identifies specific programs and projects, a set of specific measures to be implemented, deadlines, responsible persons, funding mechanisms and other important points that ensure the achievement of goals.

Implementation and evaluation. Progress in community development is obvious when change occurs and when people can see concrete results. This stage is when individuals, groups and organizations are active rather than passive participants in community life. Before the implementation of the community development process, individuals and organizations make great efforts to understand what they have, what their thoughts and commitments are, to come 
to a common vision of their own future, to agree on priority future activities and strategies, but at the implementation stage all these efforts are realized.

Public participation. Determining the future of a community and how it will get from "point A" to "point B" is an important task. If community members do not want someone else to determine their future for them (and this happens very often), they must be proactive and involved in determining the directions of development of their community.

Regarding the specification of regional development in the context of the implementation of a consistently democratic concept, it is necessary to note the importance of the principle of subsidiarity, which can be defined as a line of growing subjectivity. That is, decision-making and its implementation is carried out from the basic level of activity of citizens to various forms of their associations and local governments, and then to higher levels of government. Thus, in accordance with the content of the European Charter of Local SelfGovernment, in the implementation of the latter to the highest level of government is transferred to address only those issues that cannot be resolved at the lowest level.

The challenge for reformers is that in districts where UTCS are formed throughout the territory, there is duplication of powers between UTC local governments, district councils and administrations. At the same time, the district state administration and the district council function there with the corresponding expenses for their maintenance, as well as the executive bodies of the UTC with the powers and financing defined by the legislation. Relevant district councils, as a rule, make decisions on monetary valuation of land and redistribution of transfers from the state budget. District state administrations are also deprived of the vast majority of powers, which by law are performed by the executive bodies of the UTC council.

An important result of the formation of local self-government in Ukraine was the understanding of the role of the territorial community in the system of Ukrainian statehood: a strong local community is the basis of a strong state. Local self-government can be the carrier of consolidation of human, local community, state power at the republican and regional levels, aimed at reviving everyone's vital forces, creating a favorable economic, social, ecological, spiritual living space for the majority of the population. This will relieve the government of the burden of day-to-day worries and enable them to focus on the main key issues of state building.

In order to improve the conditions for the formation and development of territorial communities in the context of decentralization, the following actions can be recommended:

1. it is necessary to strengthen the attraction of finance, for example through the inventory of property and assets, to conduct an audit of land plots, which will identify those lands on which there are no legal documents or misuse; 
2. create favorable conditions for business so that companies register on the territory of UTC, and both income tax and personal income tax will remain in place;

3. to involve citizens in showing initiatives to increase the efficiency of the use of funds, to create a "public budget" that will have a purpose, and the best project will be realized;

4. to carry out optimization processes, for example, Stepanivka UTC has three secondary schools, one of which is hub, with a capacity of 700 students, two schools are at a distance of $2.5 \mathrm{~km}$, the total number of students is 500 , it is necessary to transfer students to a hub school, as the maintenance of premises, teachers' salaries, current repairs are millions that are spent additionally, because optimization cannot be avoided, the situation is similar with club institutions that carry out small activities and are still nearby, and their maintenance is too expensive. In this case, the premises will be vacated and may be rented;

5. it is necessary to calculate the cost of firewood for heating and implement energy efficiency measures;

6. to strengthen the control over the use of funds for major overhauls. Therefore, it is necessary to expand the revenue base, the community decides where to send funds, but for their effectiveness, it is necessary to carry out the optimization with the proposed method.

At the state level, the main ways to improve the conditions for the development of territorial communities can be:

1. adopting the basic law "On the administrative-territorial structure of Ukraine", which defines the principles of state policy in this area, the construction of a new administrative-territorial system, unified requirements and criteria for administrative-territorial units at all levels, clear procedures for the formation and elimination of administrative territorial units, the procedure for establishing and changing their boundaries, etc.;

2. preparing and adopting a new version of the Law of Ukraine "On Local Self-Government in Ukraine", improving the functioning of full-fledged local self-government at various levels of government, redistribution of powers in the system of local self-government and between local self-government bodies and state executive bodies;

3. adopting the law "On local referendum", because with the adoption of the Law of Ukraine "On all-Ukrainian referendum" in 2012 the legal mechanism of holding a local referendum, which is a form of resolving issues of local significance by direct will, was lost;

4. amending the Law "On Cooperation of Territorial Communities" regarding the introduction of the procedure for joining territorial communities to existing cooperation agreements;

5. amending the law "On regulation of urban planning activities" to include a plan of the united territorial community, which will include functional zo- 
ning, formation of engineering and transport infrastructure, landscaping, etc. to the list of documents on spatial planning at the local level.

\section{Conclusion}

In this study, we revealed the essence of the concept of "territorial community". The interpretation of this term in the views of well-known scholars is given and a list with a brief description of the main legislative documents governing the formation of a territorial community is given. The main properties and characteristics of territorial communities are listed and the methodology for assessing the "viability" of UTC based on economic indicators is given. For Stepanivka UTC the calculated indicators are given and its prospects are estimated. The obtained indicators for the studied UTC show that this community has never received basic and reverse subsidies during the three years of its existence, and the data obtained in Ukraine are almost identical to the data of the analyzed UTC. The coefficient of budget coverage for the studied territorial community showed that Stepanivka UTC cannot function without transfers, i.e. to cover the expenses only with its own revenues. The value of the overall tax sustainability ratio indicates that the community is able to partially cover local expenditures with tax revenues. At the end of the work, the main stages of community development as a process are given and recommendations are made to improve the conditions of formation and development of territorial communities in the conditions of decentralization in Ukraine. The empirical method used in the study proved to be liquid for Stepanivka UTC and can be used in practice to assess the "viability" of other UTCs in Ukraine. 


\section{References}

Alioshyna, N. M. (2014). Territorial community as a subject of law: extended abstract of Cand. Sci. (Law) dissertation: 12.00.01 / N. M. Alioshyna; thesis director O. V. Petryshyn. Kharkiv: NSI of state building and local selfgovernment, Yaroslav Mudryi National Law University.

Baranovska, T. M. (2016). State policy of territorial communities: content and basic approaches. At <http://nbuv.gov.ua/UJRN/ipd_2016_16_17>, accessed on 20 May 2020.

Bibik, N. V. and Shapoval, G. M. (2019.) Analysis of international experience in the development of territorial communities and determining the directions of its implementation in Ukraine. The current state of research and technology in industry, 2(8), pp. 5-14.

Bondaruk, T. (2018). Theoretical aspects of budget decentralization in the context of public administration reforms in Ukraine. In T. Bondaruk et al., eds., World of Finances, 2. pp. 7-19.

Bulkovsky, T. O. (2013). Decentralization of administrative services of internal affairs bodies of Ukraine. Kharkiv: Investments: practice and experience. 8, pp. 166-169.

Constitution of Ukraine.Vedomosti The Verkhovna Rada of Ukraine (VVR). (1996). 30, p. 141. At: <http://zakon5.rada.gov.ua/laws/show/254\%D0\%BA /96-\%D0\%B2\%D1\%80> accessed on 20 May 2020.

Dudley, W. (2019). Ukraine's Decentralization Reform. Berlin: German Institute for International and Security Affairs, p. 34.

European Charter of Local Self-Government (2020). At <http://zakon2.rada.gov. ua/laws/show/994_036./> accessed on 20 May 2020.

Ignatenko, O. S. (2016). Criteria for assessing the effectiveness of interaction between local authorities in Ukraine. In O. S. Ignatenko and V. I. Dudar, eds., Bulletin of the National Academy of Public Administration under the President of Ukraine. Public Administration, 3, pp. 43-47.

Klymenko, A. V. (2019). Explanatory note to the decision of the twenty-sixth session of the 7th convocation of the Stepanivka village council of December 21, 2019 "On the budget of the 35th Stepanivka village united territorial community for 2020".

Kravchenko, V. V. (2015). Significance and role of population self-organization bodies in the system of local self-government in Ukraine: a functional approach Kyiv. Theory and practice of public administration, 1, pp. 159-164.

Kyrylenko, O. P. (2015). Planning and management of financial resources of the territorial community. Association of Ukrainian Cities. Kyiv: VAN ENTERPRISE LLC, p. 396.

Lipentsev, A. V. (2015). Administrative services in Ukraine: concept and essence. In A. V. Lipentsev and Yu. S. Zhuk, eds., Efficiency of public administration: a collection of scientific papers, p. 42.

Moroz, O. (2008). Territorial community: the essence of formation and modern Ukrainian realities. Democratic governance, 2. At <www. nbuv. gov. ua>, accessed on 20 May 2020.

Negoda, V. (2017). Decentralization as the basis for the formation of an effective system of governance and local development. Kyiv: Development strategy. 4, pp. 3-9. 
Popok, A. A. (2017). Innovative activity in public authority: a systematic approach. In A. A. Popok and S. A. Popov, eds., Kyiv: Bulletin of the National Academy of Public Administration under the President of Ukraine. 2, pp. 12-19.

Seryogin, S.M. (2016). Management of strategic development of united territorial communities: innovative approaches and tools: monograph. Dnipro: DRIPA NAPA, p. 276.

Skrypniuk, O. (2015). Decentralization of power as a factor in ensuring the stability of the constitutional order: theory and practice. Kyiv: Viche: sociopolitical and theoretical journal, 12, pp. 22-24.

Svendsen, L. (2016). Philosophy of Freedom. Lars Fr. G. Svendsen; transl. from Norwegian. Lviv: Anetti Antonenko Publishing House; K.: Nika-Center.

The Law of Ukraine. (2015). On the Local Elections from 14. 07. 2015, 595(8). At <http://zakon3.rada. gov.ua/laws/ show/595-19>, accessed on 20 May 2020.

The Law of Ukraine. (1997). On Local Self-Government from 1997, 24. At <https://zakon.rada.gov.ua/laws/show/280/97-\%D0\%B2\%D1\%80\#Text>, accessed on 20 May 2020.

The Law of Ukraine. (2015). On Voluntary Association of Territorial Communities from 05.02.2015. 157(8), Vidomosty of the Verkhovna Rada, p. 91.

Voytovych R.V. and Vorona P.V. (2018). Scientific and practical support for decentralization of services in the united territorial communities: materials of science - practical conf. Kyiv: IPT SES, p. 360.

Yeroshenko K. M. and Semygina T. V. (2017). Information and educational activities of public advisers in the context of decentralization processes in Ukraine. Municipal reform in the context of European integration of Ukraine: the position of government, scientists, trade unions and the public: Abstracts of All-Ukrainian Science - practical conf. Kyiv, pp. 139-142.

Zhalilo Ya. A. (2019). Decentralization of power as an institutional factor of systemic transformation of the economy. Kyiv: Bulletin of socio-economic research, 1(69). 